\title{
ОБ УЖЕСТОЧЕНИИ ОТВЕТСТВЕННОСТИ ЗА НАРУШЕНИЕ ЗАКОНОДАТЕЛЬСТВА В СФЕРЕ ОБОРОТА ЛЕКАРСТВЕННЫХ СРЕДСТВ
}

\begin{abstract}
Аннотация: Предметом настоящего исследования является ответственность за нарушения законодательства в сфере оборота лекарственных средств. Объектом исследования выступает законодательство Российской Федерации, устанавливающее ответственность за нарушение любых правил в сфере обращения лекарственньх средств. Автор обращает внимание на направления по которыли ведется борьба на территории Российской Федераџии с поддельныли лекарственныли средствами. Актуальность исследования обуславливается статистическими даннылм, которые фиксируют высокую смертность от фальсифицированных лекарственньх средств и при этом низкий процент привлечения к ответственности. В процессе исследования были использованы ряд общенаучных и специальных методов, в том числе статистический, метод анализа и ряд других. Основными выводами исследования являются предложения по систематизаџии работь в области ужесточения ответственности за преступления и правонарушения за производство, продажу или ввоз на территорию РФ фальсифицированных, контрафактных, недоброкачественных и незарегистрированных лекарственных средств, медицинских изделий и оборот фальсифицированных биологически активных добавок, а также разграничение уголовной и административной ответственности.
\end{abstract}

Ключевые слова: Ответственность, нарушение законодательств, лекарства, медицина, административная ответствненость, уголовная ответственность, предель ответственнности, здоровье, поддельные лекарства, изменение законодательства.

Abstract: The subject of this research is the responsibility for violations in the area of illegal prescription drug trade. The object of the research is the legislation of the Russian Federation, which sets the responsibility for violation of any rules in the sphere of prescription drugs. The author turns his attention to the vectors of fight against counterfeit prescription medication on the territory of Russian Federation. The relevance of this research is justified by the statistical data that records a high mortality rate caused by counterfeit medicines, and a very low percentage of indictments. Among the main conclusions are the proposals to systematize the work in the area of toughening the punishment for crimes and violations of manufacturing, sale, or trafficking of fake, counterfeit, and low-grade or unregistered medicines, and trade of medical products and dietary supplements on the territory of the Russian Federation, as well as the demarcation of criminal and administrative responsibility.

Keywords: Health, responsibility limits, criminal liability, administrative liability, medecine, drugs, violation of the law, liability, counterfeit drugs, legislation change.

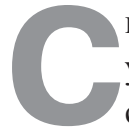

начала 2015 года в Российской Федерации была ужесточена ответственность за нарушения в сфере торговли лекарствами.

Федеральным законом от 31.12.2014 N 532-Ф3 [1] была изменена ст. 6.28 Кодекса РФ об административных правонарушениях [2], устанавливающая ответственность за нарушение правил обращения лекарственными средствами.

Ст. 6.28 КоАП РФ была введена в конце 2013 г. Федеральным законом от 25.11.2013 N 317-Ф3 [3]. В первоначальной редакции данная статья устанавливала одинаковую ответственность за нарушение любых правил в сфере обращения лекарственных средств - наложение административного штрафа незначительного размера: на граждан в размере от двух до четырех тысяч рублей; на должностных лиц - от пяти до десяти тысяч рублей; на юридических лиц - от тридцати до пятидесяти тысяч рублей. Между тем под ее действие попадали, в том числе, изготовление и импорт поддельных лекарственных средств и торговля ими на территории РФ, незаконное производство лекарств и т.д. Очевидно, что негативные последствия от производства и продажи поддельных лекарственных средств несоразмерно больше последствий от многих других нарушений в сфере торговли и оборота лекарств, например допущения формальной ошибки в экспертизе качества лекарства.

Все поддельные лекарственные средства, с которыми ведется борьба на территории РФ можно условно разделить на 3 большие группы: 
- фальсифицированные лекарственные средства;

- недоброкачественные лекарственные средства;

- контрафактные лекарственные средства.

К первой группе относятся лекарства, которые сопровождаются ложной информацией об их характеристиках и (или) производителе.

Вторую группу составляют лекарственные средства, не соответствующие требованиям нормативной, технической, эксплуатационной и иной документации.

К контрафактным лекарственным средствам относятся препараты, находящиеся в обороте с нарушением гражданского законодательства (например, с нарушением законодательства об охране интеллектуальной собственности).

Лишь по официальным данным Росздравнадзора за 2013 г. в РФ было выявлено и изъято из обращения более 2,8 млн. упаковок недоброкачественных, фальсифицированных и незарегистрированных лекарственных средств [4]. При таких масштабах изготовления и распространения поддельных лекарств штрафы, установленные ст. 6.28 КоАП РФ, не могли остановить производителей и торговцев фальсифицированной продукцией. Необходимо было ужесточать наказание за подобные нарушения.

Федеральный закон от 31.12.2014 N 532 ввел в КоАП РФ новую статью 6.33 , которая установила ответственность исключительно за производство, продажа или ввоз на территорию РФ фальсифицированных, контрафактных, недоброкачественных и незарегистрированных лекарственных средств, медицинских изделий и оборот фальсифицированных биологически активных добавок. Пределы ответственности были значительно увеличены по сравнению со ст. 6.28 КоАП РФ: за совершение правонарушений, указанных в ст. 6.33 КоАП РФ, предусмотрено наложение административного штрафа на граждан в размере от семидесяти тысяч до ста тысяч рублей; на должностных лиц - от ста тысяч до шестисот тысяч рублей; на индивидуальных предпринимателей - от ста тысяч до шестисот тысяч рублей или административное приостановление деятельности на срок до девяноста суток; на юридических лиц - от одного миллиона до пяти миллионов рублей или административное приостановление деятельности на срок до девяноста суток.

Дела по административным правонарушениям, предусмотренным ст. 6.33 КоАП РФ по общему правилу рассматриваются мировыми судьями или арбитражными судами, в случае если нарушение совершено юридическим лицом или индивидуальным предпринимателем [2].
К лицам, которые могут составлять протокол об административном правонарушении, предусмотренном ст. 6.33 КоАП РФ, закон относит:

- должностных лиц таможенных органов (п. 12 ч. 2 ст. 28.3 КоАП РФ);

- должностных лиц органов, осуществляющих функции по контролю и надзору в сфере здравоохранения (кроме нарушений, связанных с оборотом фальсифицированных биологически активных добавок) (п. 18 ч. 2 ст. 28.3 КоАП РФ);

- должностных лиц органов, осуществляющих федеральный государственный надзор в области защиты прав потребителей (п. 63 ч. 2 ст. 28.3 КоАП РФ).

Рассмотрение дел по административным правонарушениям, предусмотренным ст. 6.28 КоАП РФ, отнесено к исключительной компетенции федерального органа исполнительной власти, осуществляющего функции по контролю и надзору в сфере здравоохранения (и его территориальных органов).

Кроме того, с января 2015 г. была введена также и уголовная ответственность за нарушение части правил оборота лекарств. В частности, ст. 235.1 Уголовного Кодекса РФ[5] установила ответственность за производство лекарственных средств или медицинских изделий без специального разрешения (лицензии), если такое разрешение (такая лицензия) обязательно (обязательна), а ст. 238.1 УК РФ - за обращение фальсифицированных, недоброкачественных и незарегистрированных лекарственных средств, медицинских изделий и оборот фальсифицированных биологически активных добавок в крупном размере.

Пределы ответственности, установленные ст. 6.28 КоАП РФ, не были изменены. Представляется, что это не было необходимым, поскольку введение уголовного наказания за самые серьезные нарушения в сфере обращения лекарственных средств уже отделило их от иных, не столь значительных правонарушений.

Важным в борьбе с поддельными лекарственными средствами является также то, что наряду с указанными выше статьями, в УК РФ введена ст. 372.2 , устанавливающая уголовную ответственность за подделку документов на лекарственные средства или медицинские изделия или подделку первичной упаковки и (или) вторичной (потребительской) упаковки лекарственных препаратов.

Системное проведение всех указанных выше реформ, несомненно, будет иметь положительный эффект в борьбе с рынком поддельных лекарственных средств. Принятие Федерального закона от 31.12.2014 N 532-Ф3 позволило не только отделить производство и торговлю 
DOI: $10.7256 / 1811-9018.2015 .9 .14439$

При цитировании этой статьи сноска на dоі обязательна

\section{Право и политика 9 (189) $\bullet 2015$}

фальсифицированным продуктом от иных нарушений в сфере оборота лекарств, но и разграничить сами нарушения по производству и торговле фальсификатом в зависимости от их размера. Уголовная ответственность по ст. 238.1 наступает при обороте фальсифицированных, недоброкачественных и незарегистрированных лекарственных средств, медицинских изделий, биоло- гически активных добавок на сумму более 100 тысяч рублей, в иных случаях наступает административная ответственность с наложением крупных штрафов.

Указанные меры позволят эффективно бороться не только с крупными производителями и распространителями поддельных лекарств, но и с более мелкими дельцами.

\section{Библиография:}

1. Федеральный закон от 31.12.2014 N 532-Ф3 «О внесении изменений в отдельные законодательные акты Российской Федерации в части противодействия обороту фальсифицированных, контрафактных, недоброкачественных и незарегистрированных лекарственных средств, медицинских изделий и фальсифицированных биологически активных добавок» // Собрание законодательства РФ, 05.01.2015, N 1 (часть I), ст. 85.

2. Кодекс Российской Федерации об административных правонарушениях от 30.12.2001 N 195-Ф3 (ред. от 31.12.2014) (с изм. и доп., вступ. в силу с 05.02.2015) // Собрание законодательства РФ, 07.01.2002, N 1 (ч. 1), ст. 1.

3. Федеральный закон от 25.11.2013 N 317-Ф3 «О внесении изменений в отдельные законодательные акты Российской Федерации и признании утратившими силу отдельных положений законодательных актов Российской Федерации по вопросам охраны здоровья граждан в Российской Федерации» // Собрание законодательства РФ, 02.12.2013, N 48, ст. 6165.

4. Федеральный закон от 02.01.2000 N 29-Ф3 (ред. от 31.12.2014) «О качестве и безопасности пищевых продуктов», ст. 1 // Собрание законодательства РФ, 10.01.2000, N 2, ст. 150.

5. М.А. Мурашко. Итоги работы Федеральной службы по надзору в сфере здравоохранения и ее территориальных органов по субъектам Российской Федерации в 2013 г. (по материалам итоговой коллегии Росздравнадзора). // Вестник Росздравнадзора, №2, 2014. С. 7-17.

6. Федеральный закон от 21.11.2011 N 323-Ф3 (ред. от 01.12.2014) «Об основах охраны здоровья граждан в Российской Федерации» (с изм. и доп., вступ. в силу с 01.01.2015) // Собрание законодательства РФ, 28.11.2011, N 48, ст. 6724.

7. Федеральный закон от 12.04.2010 N 61-Ф3 (ред. от 22.10.2014) «Об обращении лекарственных средств» (с изм. и доп., вступ. в силу с 01.01.2015) // Собрание законодательства РФ, 19.04.2010, N 16, ст. 1815.

8. Уголовный кодекс Российской Федерации» от 13.06.1996 N 63-Ф3 (ред. от 31.12.2014) (с изм. и доп., вступ. в силу с 23.01.2015) // Собрание законодательства РФ, 17.06.1996, N 25, ст. 2954.

\section{References (transliterated):}

1. M.A. Murashko. Itogi raboty Federal'noi sluzhby po nadzoru v sfere zdravookhraneniya i ee territorial'nykh organov po sub"'ektam Rossiiskoi Federatsii v 2013 g. (po materialam itogovoi kollegii Roszdravnadzora). // Vestnik Roszdravnadzora, №2, 2014. S. 7-17. 